\title{
До питання визначення кінематичних параметрів зернозбиральних комбайнів
}

\author{
Г.І. Барабаш, О.В. Таценко \\ Сумський національний аграрний університет (м.Суми, Україна)
}

\begin{abstract}
Пошуки ефективних рішень в технологіях збирання зернових культур ведуться через впровадження нових підходів і способів виконання елементів технологічних операцій та підбір технічних засобів для якісного їх виконання.

Одним із напрямків вдосконалення використання технічних засобів є дослідження і обґрунтування роботи машинних агрегатів на робочих ділянках через оптимізацію їх кінематичних показників при русі по полю. Проблема полягає в тому щоб встановити залежності кінематичних показників використання технічних засобів, а в технологічному процесі збирання зернових культур зернозбирального комбайна, від схем руху і способів його повороту шляхом математичного моделювання.

Для самохідних зернозбиральних комбайнів ширина захвату визначається шириною захвату жниварки. Конструкційна ширина захвату жниварки залежить, як правило, від класу комбайна. При застосуванні рядової системи, як показали наші спостереження, недовикористання захвату жниварки може складати 15-20 см, а високоточних - до 10 см. Цей показник ні в якій мірі не залежить від способів руху і видів повороту комбайна.

Єдиним способом руху комбайна при збиранні зернових культур на полях правильної форми $\epsilon$ круговий спосіб - в складок (від периферії до центру). Як показали наші аналітичні розрахунки, проведені на базі комбайна зернозбирального ПАЛЕССE GS 12 з шириною захвату жниварки 7м при розмірі поля 150 га та різними схемами поворотів (з боковою закритою петлею; з використанням заднього ходу; з використанням діагонального прокосу),

у всіх трьох варіантів коефіцієнт використання робочих ходів доволі високий. Але найбільше значення має той коефіцієнт, де організований рух комбайна на загінці з прокосами. Ця схема руху агрегату має ще одну позитивну сторону: в місцях, де виконується цей холостий хід не потрібно знижувати швидкість або переключати реверс, як це в інших варіантах.
\end{abstract}

Ключові слова: збирання, комбайн, способи руху, схеми поворотів, кінематика, коефріцієнт робочих ходів, коефіцієнт поворотливості.

Постановка проблеми у загальному вигляді. Пошуки ефективних технологічних рішень та заходів в технологіях збирання зернових сільськогосподарських культур ведуться через впровадження нових підходів i способів виконання технологічних операцій в збиральних процесах та підбір технічних засобів для якісного їх виконання.

Технологічні процеси збирання зернових культур $є$ основними складовими частинами зональних науково обґрунтованих систем виробництва продукції сільськогосподарських культур. Особливо важливе значення вони набувають в сучасних умовах, коли істотно погіршується ресурсне забезпечення та пошук шляхів по їх ефективному використанню[1].

Одним із напрямків вдосконалення використання технічних засобів у технологічних процесах виробництва продукції сільськогосподарських культур є дослідження і обґрунтування роботи машинних агрегатів на робочих ділянках через оптимізацію їх кінематичних показників при русі по полю.

Проблема полягає в тому щоб встановити залежності кінематичних показників використання технічних засобів, а в технологічному процесі збирання зернових культур зернозбирального комбайна, від схем руху і способів його повороту шляхом аналітичного та математичного моделювання.

Аналіз останніх досліджень і публікацій.

Проблема вивчення і вдосконалення способів руху та типів поворотів в технологічних операціях, в тому числі і процесів збирання зернових культур є важливою для ефективності використання систем і комплексів машин в Україні на протязі значного періоду часу.

Визначення ефективності роботи машинних агрегатів в рослинництві повною мірою пов'язане з їх кінематичними характеристиками, які безпосередньо будуть впливати на коефіцієнт використання робочого часу будь-якого машинного агрегату. Це стосується також зернозбиральних комбайнів, які $\epsilon$ найбільш складним технічним засобом в аграрному виробництві.

В останній час наукові дослідження в питанні використання технічних засобів в технологічних процесах направлені на визначення раціональної структури затрат для виконання технологічних процесів через обґрунтування складу машинних агрегатів та режимів їх роботи. У роботах М.К. 
Діденка, В.Д. Гречкосія, І.І. Мельника, С.М. Бондаря [1] розроблена методика, яка дає змогу визначити раціональні структури машинних агрегатів для виконання технологічних процесів в системах технологій виробництва продукції рослинництва де також враховуються питання кінематики руху машинних агрегатів.

Також питанню кінематики використання машинних агрегатів при розробці операційній технології розглядалось в роботі [2] науковцями Г.І. Барабаш, В.М. Зубко, О.Г. Барабаш, Т.В. Хворост.

Аналітичні дослідження стосовно кінематичних характеристик роботи машинних агрегатів (комбайнів) при виконанні технологічних операцій та оцінки ефективності їх роботи в залежності від виробничих умов мало проводились.

Формулювання цілей статті (постановка завдання). Обґрунтування раціональних складів і режимів роботи машинних агрегатів повинно опиратися на систему математичних моделей, які відтворюють взаємозалежність між умовами роботи і вимогами до технологічних процесів.

В технічній літературі та підручниках по виробничій експлуатації машин і обладнання в рослинництві $€$ інформація стосовно того, як визначаються кінематичні параметри машинних агрегатів взагалі, але стосовно роботи комбайнів інформації мало і зовсім вона відсутня про залежність кінематичних показників від схем руху та способів повороту зернозбиральних комбайнів.

Забезпечення виконання перелічених вище задач полягає в тому, щоб надати методичні підходи по визначенню основних кінематичних показників зернозбиральних комбайнів в різних умовах їх використання, що дасть можливість вибрати найбільш раціональні способі руху і види поворотів які забезпечать: підвищення продуктивності, зменшення витрат енергетичних ресурсів, якісне виконання робіт по необхідних критеріях.

Теоретичні передумови наукового дослідження. Пошуки ефективних технологічних рішень та заходів в технологіях виробництва сільськогосподарської продукції ведуться через впровадження нових підходів і способів в технологічних процесах та підбір технічних засобів для якісного їх виконання, в тому числі і при проведенні технологічних операцій збирання сільськогосподарських культур зернозбиральними комбайнами.

Теоретичні передумови визначення кінематичних параметрів.:

Робоча ширина захвату , $B_{\mathrm{p}}$ :

$$
B_{\mathrm{p}}=\beta \cdot B_{\mathrm{K}}
$$

де $\beta$ - коефіцієнт використання ширини захвату; $B_{\text {К }}$ - конструкційна ширина захвата робочої машини.
Для самохідних зернозбиральних комбайнів ширина захвату визначається шириною захвата жниварки - хедера (при прямому комбайнуванні) або шириною захвата валкової жниварки (при роздільному способі збирання). Конструкційна ширина захвата жниварки залежить, як правило, від класу комбайна - чим вища продуктивність комбайна тим більша ширина захвата, що дає можливість більш повно використати технічні можливості комбайна. Цей показник відображається в технічній характеристиці комбайна. В звичайних виробничих умовах коефіцієнт $\beta$ теж, як правило, залежить прямо пропорційно від ширини захвату жниварки. Він знаходився в межах 0,93...0,96 в залежності від ширини захвату жниварки. В передових господарствах, де застосовуються навігаційні системи, такої прямої залежності не існує. При застосуванні рядової системи, як показали наші спостереження, недовикористання захвату жниварки може складати 15-20 см, а високоточних - до 10 см. Але ці системи дуже дорогі. Цей показник ні в якій мірі не залежить від способів руху і видів повороту комбайна.

Способи руху та види поворотів.

Перед тим, як вибирати способи руху і схему поворотів (Рис. 1) виконавці повинні дотримуватись одної беззаперечної вимоги: поле повинно бути поділене на загінки, якщо його площа перевищує 50 га. Крім того поле повинно бути обкошеним по периметру, а потім зроблені прокоси між загінками, потім вслід за комбайном необхідно скошені смуги обробити ґрунтообробним машинним агрегатом (як правило, плужним).

Єдиним способом руху комбайна при збиранні зернових культур на полях правильної фрорми є круговий спосіб - в складок (від периферії до центру).

Окрім цього до загінки є ще дві вимоги:

- вона повинна мати оптимальну ширину, що потім буде позитивно відображатись на техніко-експлуатаційних показниках використання комбайну;

- розмір ширини загінки повинен бути кратним робочій ширині захвату жниварки.

Оптимальна ширина загінки $C_{\text {опт }}$ визначається за фрормулою:

$$
C_{\text {опт }}=\sqrt{3 \cdot B_{\mathrm{K}} \cdot l_{p}}
$$

де $B_{\text {к }}$-конструкційна ширина захвату жниварки, м; $l_{p}$ - робоча довжина загінки, м.

Виробничники вважають, що співвідношення короткої сторони загінки до довгої повинно бути в межах від 1:5 до 1:8. Взагалі фрормули 1,2 потребують, на наш погляд, вдосконалення. Але це окреме питання. 

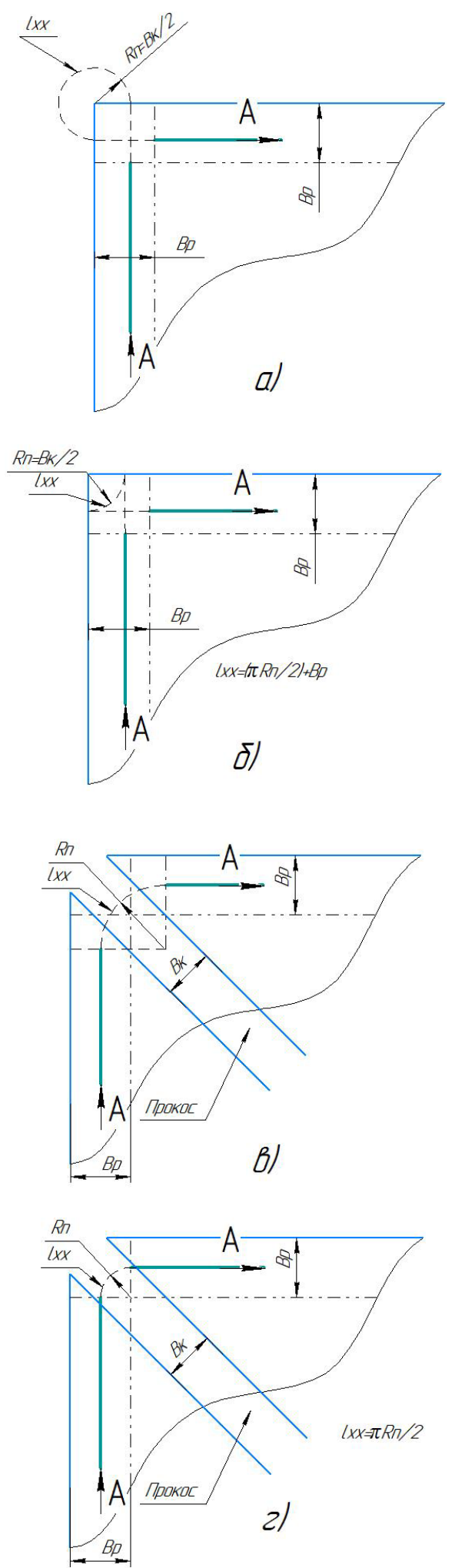

Рис. 1. Схеми повороту зернозбиральних комбайнів а) з боковою закритою петлею; б) з використанням заднього ходу; в), г) з використанням діагонального прокосу; -------- - холостий хід на повороті
При виконанні технологічного процесу радіус повороту комбайна дорівнює приблизно половині конструкційної ширини захвату жниварки.

Робоча довжина загінки $l_{p}$ по першому проходу визначається за фрормулою:

$$
l_{p}=L-2 \cdot E .
$$

де $L-$ довжина поля, м; $E$ - ширина поворотної смуги, м.

При уже обкошеному полю вкругову $E=B_{\text {к. }}$.

В комбайні можна виявити два радіуса повороту: технічний (конструкційний) та технологічний. Перший із них менший другого і він дорівнює відстані від центру повороту до кінематичного центру комбайна - середині відстані між ведучими колесами комбайна. Величина технологічного радіуса залежить від ситуації в місці повороту та конструкційної ширини захвату жниварки. 3 певною мірою достовірності можна стверджувати, що величина технологічного радіусу повороту буде дорівнювати половині конструкційної ширини захвату, тобто:

$$
R_{\mathrm{\Pi}}=0,5 \cdot B_{\mathrm{K}} .
$$

Але радіус повороту нам потрібен не сам по собі, а для того, щоб можна було визначити довжину шляху холостого ходу при здійсненні цього повороту. Щоб визначити довжину цього шляху потрібно ще знати довжину виїзду комбайна - це відстань на яку необхідно проїхати кінематичним центром комбайна від контрольної лінії на поворотній смузі до початку повороту, щоб попередити пошкодження рослин або виключити огріхи.

Тоді довжина шляху при здійсненні холостого повороту $l_{\mathrm{xx}}$ на $90^{\circ}$ буде дорівнювати довжині кола радіусом $R_{\text {п }}$ п поправкою на виїзд із загінки та заїзд в загінку, тобто:

$$
l_{\mathrm{XX}}=2 \cdot \pi \cdot \frac{3}{4} \cdot R_{\text {п }}+l_{\mathrm{B}}+l_{3},
$$

де $l_{\text {в }}$ - відстань можливого виїздужниварки (на рівні ножів)за межі контрольної лінії; $l_{3}$ - відстань заїзду в робочу загінку після повороту.

Очевидно, що $l_{3}=B_{\mathrm{p}}$.

Величина виїзду $l_{\text {в }}$, як правило, буде знаходитись в межах від нуля до довжини шляху, який пройде різальний апарат жниварки за межі контрольної лінії при виїзді із робочої загінки.(це не більше ширини днища жниварки). Цей показник характеризує майстерність механізатора.

Після перетворення (5) отримаємо:

$$
l_{\mathrm{XX}}=2,4 \cdot B_{\mathrm{K}}+l_{\mathrm{B}}+B_{\mathrm{p}}
$$

Якщо прийняти до уваги, що при точному водінні комбайна $l_{\mathrm{B}}=0$, а $B_{\mathrm{\kappa}}=B_{\mathrm{p}}$, то

$$
l_{\mathrm{XX}}=3,4 \cdot B_{\mathrm{K}} \text {. }
$$


Довжина шляху при здійсненні холостого повороту $l_{\mathrm{xx}}$ на $90^{\circ}$ з застосуванням заднього ходу буде дорівнювати 1/4 довжині кола радіусом $R_{\text {п }}$ з поправкою на виїзд із загінки та заїзд в загінку, тобто:

$$
l_{\mathrm{XX}}=0,8 \cdot B_{\mathrm{K}}+l_{\mathrm{B}}+l_{3},
$$

При високоточному водінні комбайна можна записать:

$$
l_{\mathrm{XX}}=1,6 \cdot B_{\mathrm{K}} .
$$

При русі комбайна в загінці вкругову, де попередньо виконані кутові прокоси (рух по «конверту»), то довжина холостого $l_{\mathrm{xx}}$ ходу буде дорівнювати конструкційній ширині захвату жниварки $B_{\text {к }}$,

$$
l_{\mathrm{XX}}=B_{\mathrm{K}} / \sin 45^{\circ}=1,4 \cdot B_{\mathrm{K}} .
$$

Якщо цього не досить при малій ширині захвату жниварки, то

$$
l_{\mathrm{XX}}=1,4 \cdot\left(B_{\mathrm{K}}+B_{\mathrm{p}}\right)=2,4 \cdot B_{\mathrm{K}}
$$

Коефіцієнт робочих ходів, $\varphi$ :

$$
\phi=\frac{\sum l_{p}}{\sum l_{p}+\sum l_{x . x}}=\frac{l_{p} \cdot n_{p}}{l_{x x} \cdot n_{x x}+l_{p} \cdot n_{p}},
$$

де $n_{p}, n_{x x}$ - відповідно число робочих та холостих проходів по полю.

Кількість робочих проходів машинного агрегату на загінці:

$$
n_{p}=\frac{C_{\text {опт }}}{B_{p}} .
$$

Кількість холостих ходів (поворотів) на загінці:

$$
n_{x x}=\frac{C_{\text {опт }}}{B_{P}}-1=n_{p}-1 .
$$

Коефіцієнт поворотливості $K_{\Pi}$, $\left(\mathrm{M}^{2}\right)$, являє собою добуток радіуса повороту $R_{\text {п }}$ на шлях $S$, який необхідно пройти агрегату, щоб досягти цього радіуса. Він характеризує як швидко агрегат входить у поворот (рух по клотоїді), тобто його поворотливість і називається показником поворотливості.

$$
K_{\Pi}=R_{\Pi} \cdot S .
$$

В нашому випадку рух по клотоїді відсутній, то

$$
K_{\Pi}=R_{\Pi} .
$$

Результати дослідження.

Розглянемо і продемонструємо наші твердження на наступному прикладі.

Для обґрунтування кінематичних показників роботи зернозбирального комбайна ПАЛЕССЕ GS 12 для виробничих умов Сумщини було проведено розрахунки згідно запропонованої методики, яка представлена вище.
Продемонструємо це прикладом, маючи наступні вихідні дані:

комбайн зернозбиральний ПАЛЕССE GS 12 (рис. 2):

- $\quad$ ширина захвату жниварки $B_{\mathrm{K}}=7 \mathrm{M}$.

- розміри поля: площа $F=150$ га; довжина $L=1500$ м; ширина $B=1000$ м.

Послідовність обгрунтування згідно методики.

1.Робоча довжина загінки по першому проходу: $l_{p}=1500-2 \cdot 7=1486($ м)

2.Оптимальна ширина загінки при рухові уздовж поля: при $B_{\mathrm{p}}=6,9$ м та парній кількості проходів комбайна $C_{\text {опт }}=179 \mathrm{м}$.

3.Довжина холостого ходу по варіантах:

а) - визначена за фрормулою (7)

$l_{\mathrm{Xx}}=3,4 \cdot B_{\mathrm{K}}=23,8(\mathrm{M})$;

б) - визначена за фрормулою (9)

$l_{\mathrm{XX}}=1,6 \cdot B_{\mathrm{K}}=11,2(\mathrm{~m})$;

В) - визначена за фрормулою (10)

$l_{\mathrm{XX}}=1,4 \cdot B_{\mathrm{K}}=9,8(\mathrm{M})$.

4.Кількість робочих ходів $n_{\mathrm{p}}=26$.

5.Кількість холостих ходів $n_{x x}=25$.

6.Коефіцієнт робочих ходів відповідно по варіантах а,б,в : $\varphi=0,985 ; \varphi=0,992 ; \varphi=0,994$.

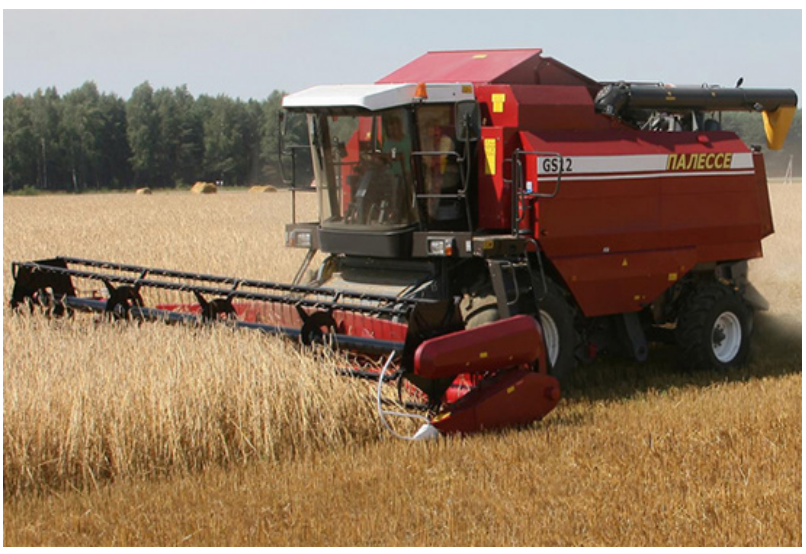

Рис.2. Комбайн зернозбиральний ПАЛЕССЕ GS 12 в роботі

\section{Висновки}

1. У всіх трьох варіантів коефріцієнт використання робочих ходів доволі високий. Але відмінність все-таки є. Найбільше значення має той коефріцієнт, де організований рух комбайна на загінці з прокосами. Тому така схема роботи комбайна найбільш раціональна. Вона має ще одну позитивну сторону: в місцях, де виконується цей холостий хід не потрібно знижувати швидкість або переключати реверс, як це в інших варіантах.

2. Отриманий результат дослідження дає можливістьдодаткових аналітичних досліджень по виявленню, як вплине ця різниця на техніко-економічні показники використання зернозбирального комбайна. 


\section{Література}

1. Оптимізація комплексів машин і структури машинного парку та планування технічного сервісу: навчальний посібник / [І. І. Мельник, В. Д. Гречкосій, В. В. Марченко та ін.]. - Київ: ВВЦ НАУ, 2004. - 151 c.

2. Методика розробки операційної технології механізованих польових робіт: навчальний посібник / В. М. Зубко, Г. І. Барабаш, О. Г. Барабаш, Т. В. Хворост. - Суми: Папірус, 2016. - 130 с.

\section{References}

1. Meljnyk, I., Ghrechkosij, V. and Marchenko, V. (2004). Optymizacija kompleksiv mashyn i struktury mashynnogho parku ta planuvannja tekhnichnogho ser-visu: navchaljnyj posibnyk. Kyjiv: VVC NAU, p.151.

2. Zubko, V., Barabash, G., Barabash, O. and Khvorost, T. (2016). Metodyka rozrobky operacijnoji tekhnologhiji mekhanizovanykh poljovykh robit: navchaljnyj posibnyk. Sumy: Papirus, p.130.

\section{Аннотация}

\section{К вопросу определения кинематических параметров зерноуборочних комбайнов}

\section{Г.И. Барабаш, А.В.Таценко}

Поиски эффективных решений в технологиях уборки зерновых культур ведутся через внедрение новых подходов и способов выполнения элементов технологических операций и подбор технических средств для качественного их выполнения.

Одним из направлений совершенствования использования технических средств является исследование и обоснование работы машинных агрегатов на рабочих участках через оптимизацию их кинематических показателей при движении по полю. Проблема заключается в том, чтобы установить зависимости кинематических показателей использования технических средств, а в технологическом процессе уборки зерновых культур зерноуборочного комбайна, от схем движения и способов его поворота путем математического моделирования.

Для самоходных зерноуборочных комбайнов ширина захвата определяется шириной захвата жатки. Конструкционная ширина захвата жатки зависит, как правило, от класса комбайна. При применении рядовой системы, как показали наши наблюдения, недоиспользование захвата жатки может составлять 15-20 см, а высокоточных - до 10 см. Этот показатель ни в коей мере не зависит от способов движения и видов поворота комбайна.

Единственным способом движения комбайна при уборке зерновых культур на полях правильной формы является круговой способ - всвал (от периферии к центру). Как показали наши аналитические расчеты, проведенные на базе комбайна зерноуборочного ПАЛЕССE GS 12 с шириной захвата жатки 7м при размере поля 150 га и различными схемами поворотов (с боковой закрытой петлей, с использованием заднего хода, с использованием диагонального прокоса),во всех трех вариантах коэффициент использования рабочих ходов достаточно высок. Но наибольшее значение имеет тот коэффициент, где организовано движение комбайна на загоне с прокосами. Эта схема движения агрегата имеет еще одну положительную сторону: в местах, где выполняется этот холостой ход не нужно снижать скорость или переключать реверс, как это в других вариантах.

Ключевые слова: уборка, комбайн, способы движения, схемы поворотов, кинематика, коеффрициент робочих ходов, коефффициент поворотливости.

\section{Abstract \\ On the question of determining the kinematic parameters of combine harvesters}

\section{G.I. Barabash, O.V. Tatsenko}

The proposed article provides methodological approaches for determining the kinematic indices of new grain combine harvesters, for which information in the source data is not yet available in literary sources. This method makes it possible to conduct analytical studies on the use of modern grain combine harvesters. In the given article also the results simulation methods movement and circuits turning movements on coefficient work moves and coefficient of turning behavior.

ISSN 2311-1828

http://enm.khntusg.com.ua
Інженерія природокористування, 2019, №3(13), с. 73 - 78

Engineering of nature management, 2019, \#3(13), p. 73 - 78 
The traditionally, the kinematic indices use of machine aggregates in crop production are determined, on technical specifications grain combine harvesters in productive conditions, and the known operating parameters of grain combine harvesters choose the required methods of movement and circuits turning movements, thus efficiency of use to the optimum value, but within a certain range of technologically accepted values.

The recent periods scientific research on this topic are aimed at determining the rational structure of costs for the implementation technological processes through substantiation the composition machine aggregates and their modes of operation.

The rationale for rational compositions and kinematics indices of grain combine harvesters should be based on a system of mathematical models that reproduce the interdependence between the working conditions and the requirements for technological processes.

The purpose of the work is to provide methodological approaches for determining the kinematics indices use of harvesting complexes, depending on the size of the fields, which will allow to further arrange the choice one of the alternative aggregates according to the necessary criteria.

The increasing the size of the fields that are harvesting of new grain combine harvesters leads to an improvement of their technical and operational performance: the unit's productivity increases, while the incremental fuel consumption decreases.

Keywords: harvesting, harvester, methods of movement, circuits turning movements, kinematics, coefficient of work moves, coefficient of turning behavior.

\section{Бібліографічне посилання/ Bibliography citation: Harvard}

Barabash, G. and Tatsenko, O. (2019). On the question of determining the kinematic parameters of combine harvesters. Engineering of nature management, (3(13), pp. $73-78$.

Подано до редакції / Received: 11.03.2019 